REVIEW ARTICLE

\title{
Volcanic activity and hazard in the East African Rift Zone
}

\author{
Juliet Biggs (1) ${ }^{1 凶}$, Atalay Ayele ${ }^{2}$, Tobias P. Fischer (1) ${ }^{3}$, Karen Fontijn (1) ${ }^{4}$, \\ William Hutchison (10 ${ }^{5}$, Emmanuel Kazimoto (i) ${ }^{6}$, Kathy Whaler (iD ${ }^{7}$ \& \\ Tim J. Wright (1D) 8
}

Over the past two decades, multidisciplinary studies have unearthed a rich history of volcanic activity and unrest in the densely-populated East African Rift System, providing new insights into the influence of rift dynamics on magmatism, the characteristics of the volcanic plumbing systems and the foundation for hazard assessments. The raised awareness of volcanic hazards is driving a shift from crisis response to reducing disaster risks, but a lack of institutional and human capacity in sub-Saharan Africa means baseline data are sparse and mitigating geohazards remains challenging.

$\mathrm{V}$ olcanoes display a diverse range of eruptive styles of varying magnitudes, intensities, and frequencies. A key control on eruptive processes is tectonic setting, which determines how magma is generated, the pathways by which it reaches the Earth's surface and the characteristics of eruptions. In extensional settings, magma is critical to weakening the lithosphere and allowing continental break-up, and the East African Rift System (EARS) provides a case study for the processes and timescales involved (Fig. $1 \mathrm{~b}-\mathrm{e}$ ). Although most regional studies of volcanism have been performed on subduction zones, $\sim 10 \%$ of the world's volcanoes lie in continental rifts including 78 in the EARS (Fig. 1a) ${ }^{1}$. Despite on-going scientific debate regarding the influence of rift dynamics on magmatism e.g. refs. ${ }^{2,3}$ and over 120 million people living within $100 \mathrm{~km}$ of an EARS volcano ${ }^{1}$, rift volcanoes are understudied in comparison to their subduction zone counterparts. Advances in remote sensing are altering our perspective on many aspects of our planet and satellite studies demonstrated that 17 EARS volcanoes experienced periods of deformation during 2003-2008 alone, most of which were previously believed to be quiescent $t^{\mathrm{e} . g 4-6}$. These observations raised important questions regarding the processes occurring at rift volcanoes and the associated hazards.

The emergent need to develop a holistic understanding of volcanism in the EARS has motivated several multi-disciplinary studies of high-risk volcanoes, approaching the problem from different perspectives. Geophysical techniques including seismology, geodesy, magnetellurics and gravity can be used to image magma storage in the rift and study the short-term processes that drive present activity (Fig. 2). It has been possible to study volcanoes throughout their eruptive cycles, including examples of explosive and effusive eruptions, dyke intrusions, unrest and quiescence. The ability to image the spatial and temporal variations in stress and

\footnotetext{
${ }^{1}$ COMET, School of Earth Sciences, University of Bristol, Bristol, UK. ${ }^{2}$ Institue of Geophysics, Space Science and Astronomy, Addis Ababa University, Addis Ababa, Ethiopia. ${ }^{3}$ Department of Earth and Planetary Sciences, University of New Mexico, Albuquerque, NM, USA. ${ }^{4}$ Department of Geosciences, Environment and Society, Université libre de Bruxelles, Av. F Roosevelt 50, 1050 Brussels, Belgium. ${ }^{5}$ School of Earth \& Environmental Sciences, University of St Andrews, St Andrews, UK. ${ }^{6}$ Department of Geosciences, University of Dar es Salaam, P. O. Box, 35052 Dar es Saalam, Tanzania. ${ }^{7}$ School of GeoSciences, University of Edinburgh, Edinburgh, UK. ${ }^{8}$ COMET, School of Earth and Environment, University of Leeds, Leeds, UK. \email: Juliet.Biggs@bristol.ac.uk
} 


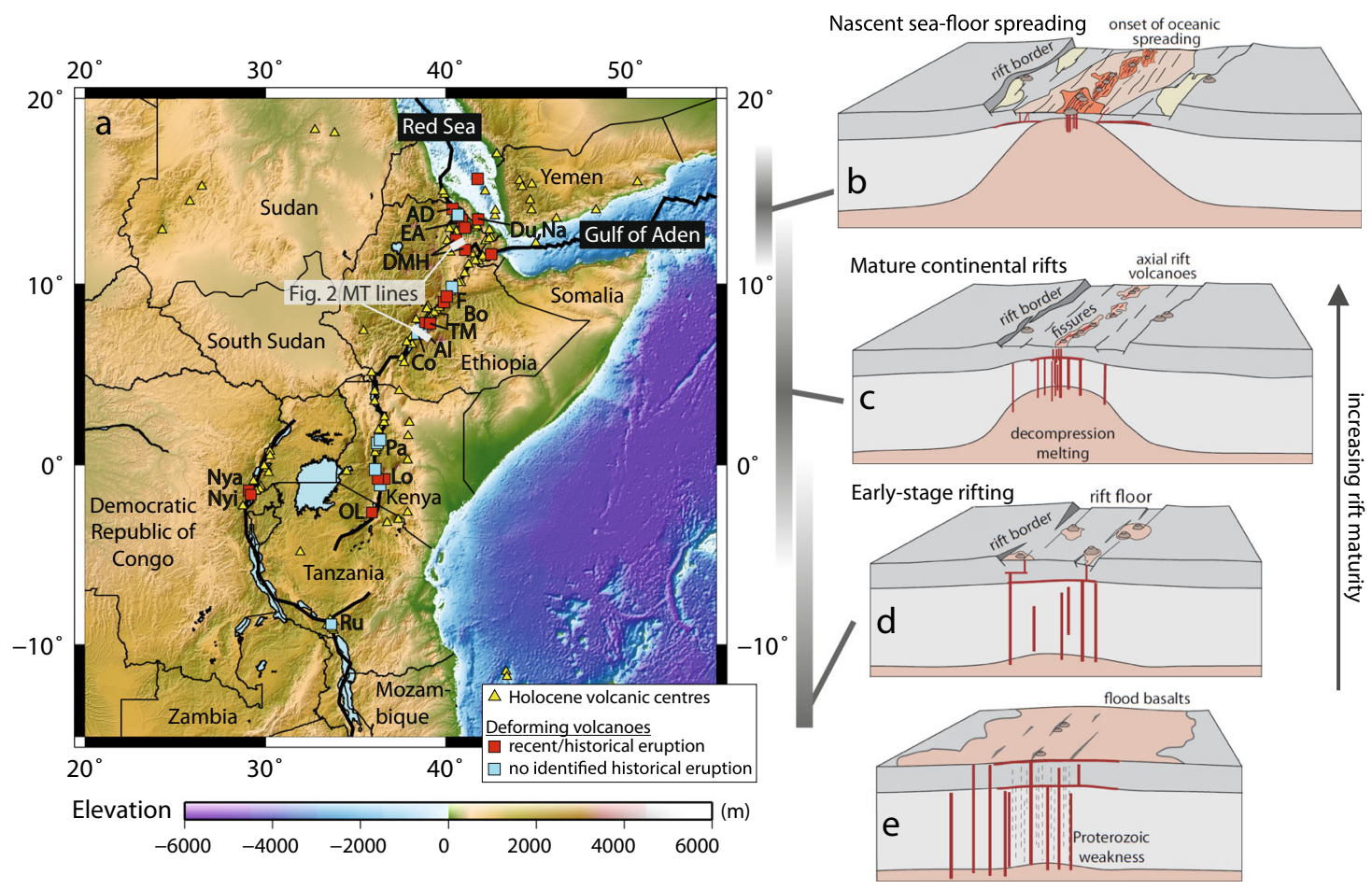

Fig. 1 Volcanoes of the East African Rift System. a Distribution of volcanoes in the East African Rift, Afar Triangle and Arabian Peninsula from ${ }^{86}$. Symbol shape denotes whether deformation has been reported (square) or not (triangle) from 6 . Colours denotes whether historical eruptions have been reported according to 80 . EA Erte 'Ale, AD Alu-Dalafilla, Du Dubbi, Na Nabro, DMH Dabbahu Manda Hararo, F Fentale, Bo Boset, TM Tullu Moye, Al Aluto, Co Corbetti, Pa Paka, Lo Longonot, OL Oldoinyo Lengai, Nya Nyamuragira, Nyi Nyiragongo, Ru Rungwe. Updated from ref. ${ }^{122}$. b-e Schematic model of continental rift evolution in the East African Rift System, modified after 8,123 . b Nascent sea-floor spreading. c Mature continental rifts, with axial rift volcanism forming large silicic centres and basaltic fissures. Extension is accommodated by a combination of faulting and magmatism. $\mathbf{d}$ Early-stage rifting, with activation of rift border faults, subsidence of a broad zone and diffuse volcanism. e Onset of rift formation concurrent with flood-basalt events.

strain associated with magmatic, hydrothermal and fault systems has provided new insights into the processes of magma storage and ascent. Although the short instrumental record is unable to capture the full range of possible behaviours, the geological record can provide information on the frequency, magnitude and characteristics of past eruptions, and geochemical analyses detail magma storage conditions within the rift.

Finally, high population exposure and vulnerability in SubSaharan Africa drive the socio-economic need to understand and manage the potential threats posed by the EARS volcanoes. However, probabilistic volcanic hazard assessment approaches that may be used to inform long-term risk management remain in their infancy in the EARS. Scientific challenges include the sparsity of data and differences in tectonic setting and magma composition, while the lack of historical disasters mean that political awareness is low.

\section{Magma storage and transport in the East African Rift System} Tectonic activity in East Africa is often attributed to the presence of mantle upwellings at various scales, but the number and depth extent of the upwellings remains debated ${ }^{7}$. The EARS comprises several discrete and diachronous rift sectors, associated with distinct styles of magmatic and volcanic activity (Fig. 1b-e) ${ }^{8,9}$. In this article, we move through the different rift stages by going from the South (early-stage rifting) to the North (sea-spreading) of the EARS. In the early stages of magmatic rifting, volcanism is characterized by unusual magmas and extreme volatile emissions (Fig. 1d). For example, Nyiragongo and its neighbour Nyamuragira are currently the fourth largest non-eruptive emitters of $\mathrm{SO}_{2}$ $\left(\sim 3500 \mathrm{t} / \mathrm{day}^{10}\right)$ globally, and also emit significant quantities of
$\mathrm{CO}_{2}\left(1 \mathrm{Mt} / \mathrm{yr}^{11}\right)$, while Oldoinyo Lengai is the only currently active natrocarbonatite volcano in the world ${ }^{12}$ (Fig. 1a).

The Kenyan Rift and the Main Ethiopian Rift (MER) are mature continental rifts (Fig. 1c), characterized by focussed upwelling and pervasive melt in the upper mantle and lower crust ${ }^{13,14}$. These rifts are dominated by large (5-15 km diameter) silicic caldera systems characterized by post-caldera rhyolitic obsidian domes, flows and pumice cones ${ }^{15}$, interspersed with distributed fields of mafic cones and lava flows ${ }^{2,16}$. Post-caldera peralkaline rhyolites formed by fractional crystallization $(>90 \%)$ at depths $<6 \mathrm{~km}(200 \mathrm{MPa})$ from parental magmas with $<1 \mathrm{wt} \%$ $\mathrm{H}_{2} \mathrm{O}^{17-20}$, and large volumes $\left(>100 \mathrm{~km}^{3}\right)$ of crystal cumulates are stored as long-lived partially crystalline mush zones with small ephemeral lenses of rhyolitic melt and exsolved volatiles ${ }^{18,20-22}$.

In the Afar region of Northern Ethiopia and Eritrea, the separation of Arabia from Nubia and Somalia over the past $30 \mathrm{Ma}$ has created a region characterized by extensive faulting, lithospheric stretching and, more recently, by intrusive and extrusive magmatic activity, thought to represent the final stages of continental break-up or the onset of sea-floor spreading (Fig. 1b) ${ }^{23}$. Observations of deformation, degassing and seismicity have allowed us to build a picture of the shallow magma storage and transport systems characteristic of the different segments of the EARS.

Early-stage rifting. In the Virunga Volcanic Province in the Democratic Republic of Congo (Figs. 1a, 3a), Nyiragongo hosts one of the world's longest-lived lava lakes fed by a shallow magma reservoir at $\sim 4 \mathrm{~km} \mathrm{depth}^{24}$. In 2002, a system of eruptive fractures opened on the southern flank, extending $20 \mathrm{~km}$ into the city of Goma, with fast-moving lava flows inundating the city, resulting 

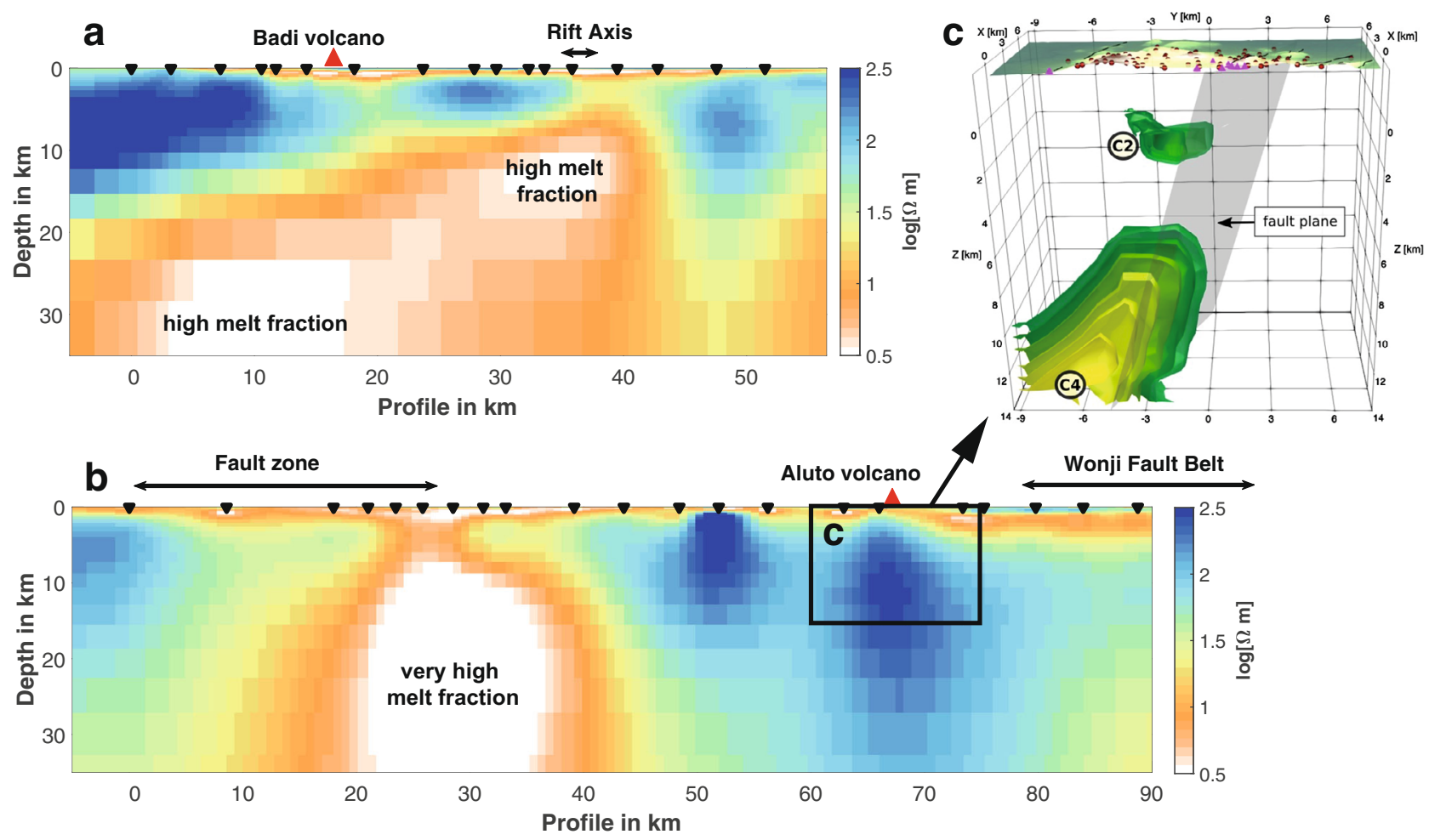

Fig. 2 Transcrustal magma storage in a continental rift. $\mathbf{a}, \mathbf{b}$ 2D models of resistivity (inverse of electrical conductivity) along profiles perpendicular to the rift axes. a The northern Dabbahu Manda Hararo magmatic segment in Afar 66 and $\mathbf{b}$ the central MER (see Fig. 1). Inverted triangles mark the locations of the MT sites projected onto the profiles. Extensive areas of warm to white colours, corresponding to high conductivity, indicate pervasive melt that extends into the upper mantle, and show the offset between lower crustal magma reservoirs and the rift axis in both Afar and MER (Aluto volcano). Moho is at $~ 22$ and $30 \mathrm{~km}$ depth beneath Afar and the central MER, respectively 64 . Petrological data suggest the bulk resistivities correspond to at least $12 \%$ melt in Afar ${ }^{66}$ and almost $60 \%$ beneath the MER ${ }^{18}$. Taken together with other information, we infer a substantial lower crustal off-axis magma reservoir in Afar and considerably higher melt fraction magma focussed into narrow zones of weakness adjacent to the rift border in the MER (Fig. 3). $\mathbf{b}$ Local-scale 3D MT study of the magmatic system under Aluto volcano showing enhanced electrical conductivity (green-yellow colours) interpreted as a lower crustal zone of melt accumulation (C4) linked to a shallow melt zone (C2) along a fault zone. From ref. ${ }^{39}$.

in $\sim 150$ fatalities and leaving $\sim 400,000$ people displaced ${ }^{25}$. Deformation patterns indicate that a $40 \mathrm{~km}$-long dyke located at $6 \mathrm{~km}$ depth triggered magma injection into a shallow eruptive reservoir, starting 10 months prior to the eruption ${ }^{26}$. More recently, an eruption in May 2021 produced lava flows that reached the city of Goma, prompting another large-scale evacuation. This eruption has also been attributed to a N-S trending dyke $^{27}$. Eruptions of neighbouring Nyamuragira on the other hand, tend to be relatively small and the 2011-2012 event produced only $\sim 0.3 \mathrm{~km}^{3}$ of magma ${ }^{28}$. Deformation and petrological studies suggest a source at $>10 \mathrm{~km}$ depth ${ }^{29,30}$.

At Oldoinyo Lengai in Tanzania (Figs. 1a, 3a), multi-decadal episodes of natrocarbonatite activity, which fill up the summit crater with extremely low-viscous and low-temperature lavas, alternate with explosive eruptions dominated by silicic nephelinite magmas ${ }^{31}$. The natrocarbonatite eruptive phases are volumetrically small compared to the silicic magmatic products ${ }^{12}$, which are thought to contribute the majority of the volatiles emitted by the volcano 32,33 . In 2007-2008, intrusion of a $7-10 \mathrm{~km}$-long dyke less than $20 \mathrm{~km}$ from the volcano preceded a new phase of explosive eruptions ${ }^{34,35}$, which generated eruption columns several kms high and spread volcanic ash over the surrounding plains ${ }^{36}$. Recent and extensive seismic studies show that the region is underlain by a complex magmatic plumbing system that extends to about $20 \mathrm{~km}$ depth, composed of interconnected layered sills that facilitate the transport of fluids (Fig. 3a) ${ }^{37}$.
Mature continental rifts. Recent geophysical experiments have enhanced our understanding of the current state of magma storage in mature continental rifts. Magnetotellurics (MT) is widely used in the geothermal exploration industry to identify high electrical conductivity clay caps associated with geothermal alteration $^{38}$ and recent improvements in data coverage and processing methods have enabled both MT and seismic tomography to successfully image the transcrustal magmatic system beneath rift calderas (Fig. 2). At Aluto (Figs. 1a, 3b), this consists of a lowvelocity, high conductivity zone of partial (10-15\%) melt at depths of $3.5-5 \mathrm{~km}$ below the surface $\mathrm{e}^{39,40}$ and a shallow hydrothermal system $(<3 \mathrm{~km})$ with high shear wave anisotropy and low $\mathrm{v}_{\mathrm{p}} / \mathrm{v}_{\mathrm{s}}$ consistent with the presence of multiple fracture sets and exsolved gases ${ }^{40,41}$. At Tullu Moye (Fig. 1a), higher conductivity in the zone of partial melt is thought to correspond to higher temperatures and melt fractions $(<33 \%)^{39}$. In the lower crust, high electrical conductivities and low seismic velocities indicate a broad zone of partial melt, extending from beneath the rift to the western boundary and in pockets beneath the western plateau, controlled by the topography of the base of the crust ${ }^{42,43}$. Extreme values of seismic anisotropy and $\mathrm{v}_{\mathrm{p}} / \mathrm{v}_{\mathrm{s}}$ along the NW rift boundary indicate melt is focussed there ${ }^{44,45}$.

Many of the caldera systems in the Main Ethiopian and Kenyan Rifts are experiencing unrest, compatible with the recharge and reorganization of shallow, long-lived mush systems. Deformation has been reported at ten EARS calderas ${ }^{6}$ and temporary seismic deployments have recorded thousands of small 


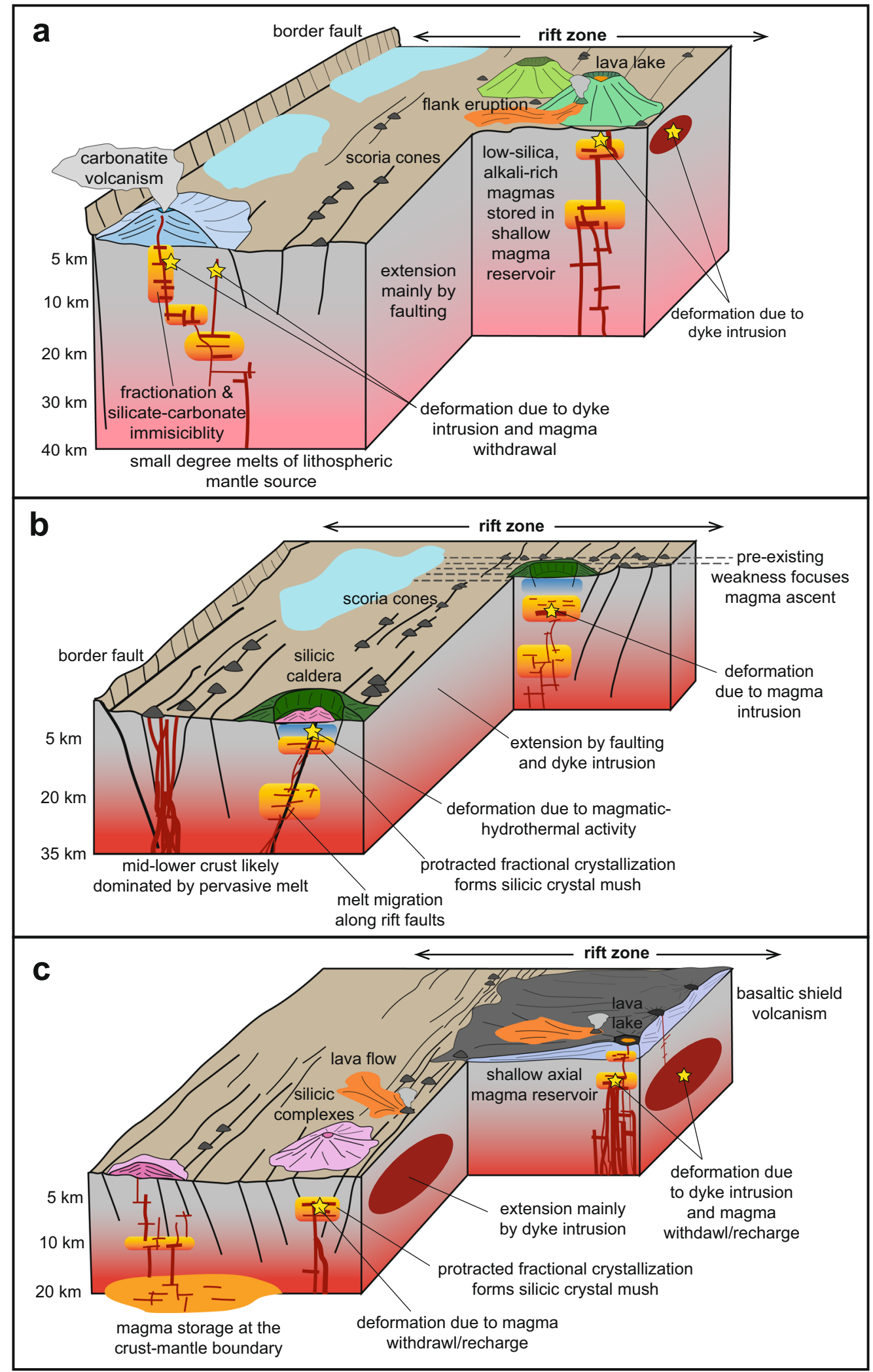

Fig. 3 Conceptual model of magmatic systems in rifts at different stages of their evolution. a Early-stage rifting, based on OI Doinyo Lengai and the Natron Rift in Tanzania (foreground), and the Virunga volcanoes on the western branch of the EARS (background). b Mature continental rifting, based on the Main Ethiopian Rift. c Nascent sea-floor spreading, based on Afar, Ethiopia, with the Manda Hararo Rift in the foreground, and the Erta Ale segment in the background. See text for details. 
magnitude $(\mathrm{M}<3)$ volcano-tectonic earthquakes ${ }^{46-50}$, as well as low-frequency events and swarms characteristic of fluid movement ${ }^{49}$. The spatio-temporal patterns of deformation are highly variable, with footprints ranging from $<1 \mathrm{~km}^{2}$ to $>150 \mathrm{~km}^{2} 6$, but are consistent with sources at the depth of fractional crystallization ${ }^{4,5,51}$. At Corbetti (Figs. 1a, 3b), sustained uplift $(>6 \mathrm{~cm} / \mathrm{yr})$ has lasted for over a decade (so far) and dynamic gravity measurements indicate a high magma flux accommodated by ductile behaviour ${ }^{6,51,52}$. In contrast, Aluto and Longonot (Fig. 1a) both experienced pulses of rapid uplift $(10-15 \mathrm{~cm})$ followed by gradual subsidence, attributed to the interaction between a deep magmatic source and shallow hydrothermal system ${ }^{5,53}$ and at Paka (Fig. 1a), four distinct, but interacting, shallow sources $(<5 \mathrm{~km})$ are required to explain the complex pattern of deformation ${ }^{54}$.

Multiple lines of evidence now agree that the large caldera systems that characterize mature continental rifting are underlain by shallow, restless magma bodies (Fig. 3b). The magmatic systems provide a heat source for abundant hydrothermal systems, giving the EARS an estimated geothermal power potential of $>15 \mathrm{GWe}^{55}$. Differences in geophysical and petrological observations between systems suggest variations in temperature, composition and structure driven by the complex interplay between the rates of tectonic and magmatic processes ${ }^{56}$.

Nascent sea-floor spreading. One of the best-studied periods of activity in the Afar region was in 2005-2010 at the Dabbahu Manda Hararo Segment (Figs. 1a, 3c), which was the first subaerial rifting episode where ground movements were mapped with satellite geodesy ${ }^{57}$. A full suite of volcanic rock types ranging from mildly alkaline basalts through to trachyandesite to peralkaline rhyolites have been erupted from the segment, with more silicic products focused around topographically-elevated volcanic centres, separated by regions of intensely fissured and faulted basaltic lava flows ${ }^{58}$. In September 2005, a dyke up to $10 \mathrm{~m}$ thick and around $65 \mathrm{~km}$-long intruded in the upper $10 \mathrm{~km}$ of $\mathrm{crust}^{59}$. The dyke was associated with a small rhyolitic ash eruption at its northern end, but evidence from regional seismicity suggested that the majority of the dyke volume was intruded from a primary source of basaltic composition at the segment centre ${ }^{60}$. Over the next 5 years, a sequence of 13 smaller dykes was intruded along the rift from the segment centre ${ }^{61}$, with local seismic stations able to show that these intrusions had a sudden onset and each took just a few hours to emplace ${ }^{62}$. Three of these smaller dykes breached the surface, erupting basaltic lavas with a transitional sub-alkaline to alkaline composition ${ }^{63}$. Later studies of ground deformation, seismology 44,65 , petrology $y^{3,58}$ and $\mathrm{MT}^{66,67}$ show that upper crustal magma reservoirs exist beneath the rift axis and silicic centres at 3-5 km depth (Fig. 3c). In contrast, the off-rift Badi volcano (Fig. 2) is underlain by a much larger zone of partial melt that extends into the mantle and is thought to persist for several tens of thousands of years ${ }^{66}$, while the inactive southern part of the segment has small volumes of partial melt in the lower crust (around $20 \mathrm{~km}$ depth) adjacent to the rift axis ${ }^{64,67}$.

Further north in Afar, at Erta 'Ale (Figs. 1a, 3c), the extension rate is slower but the crust is thinner ${ }^{23,68}$ and the rift segment is over-supplied with magma, creating a topographic ridge. At least 4 separate episodes of ground deformation have been observed along the $\sim 115 \mathrm{~km}$-long rift segment since the early $1990 \mathrm{~s}^{68-71}$. Each of these has involved intrusion along less than $10 \mathrm{~km}$ of the rift, with dyke opening confined to the upper few kilometres of crust. The 2008 activity at Alu-Dalafilla (Fig. 1a) was particularly well captured, with two $\sim 2 \mathrm{~km}$-long shallow elongated sill-like magma bodies feeding a dyke and eruption ${ }^{68}$. The most recent eruptive activity on the Erta 'Ale segment, which began in January
2017, was again consistent with a very shallow connected plumbing system of transitional basaltic composition ${ }^{72}$, with deformation due to a dyke intrusion and eruption being closely tracked by changes in the level of the lava lake ${ }^{69}$, which has been active since at least the 1960s.

Observations of activity in Afar show that dyking rather than faulting is the primary mode for accommodating extension in the elastic upper crust in mature rift systems where sufficient magma supply is available ${ }^{57}$. The behaviour of these magmatic systems is analogous to observations from spreading centres at mid-ocean ridges, where making direct observations of magma dynamics is more challenging. Activity within the Dabbahu Manda Hararo segment is comparable to slow-spreading ridges whereas at Erta 'Ale the behaviour appears more similar to fast spreading ridges despite the slow rate of extension ${ }^{57}$. Pagli et al. ${ }^{68}$ suggest the surprising behaviour at Erta 'Ale may be due to the lack of a vigorous hydrothermal circulation, excessive magma production leading to frequent magma chamber replenishment, or could be related to the proximity to the Afar plume.

Fluid flow. Noble gas isotopes, gas abundance ratios and stable isotopes of $\mathrm{C}$ and $\mathrm{N}$ unequivocally demonstrate the significance of mantle-derived components to volatile discharges throughout the rift implying that the EARS provides a major pathway for deep earth gases to the atmosphere ${ }^{73-75}$. While these fluids contain C, S, H species and noble gases, most work to date has focussed on quantifying the flux of $\mathrm{CO}_{2}$ from the rift system. This requires ground-based spot measurements over strategically selected areas of the vast rift system followed by extrapolation to areas that have not yet been measured. The estimates of $\mathrm{CO}_{2}$ flux from the entire eastern branch of the EARS range from 4 to $33 \mathrm{Mt}$ $\mathrm{CO}_{2} / \mathrm{yr}^{76}$ to $71 \pm 33 \mathrm{Mt} \mathrm{CO}_{2} / \mathrm{yr}^{77}$. These large uncertainties demonstrate the challenges to accurately quantifying emissions from large-scale continental rifts and are likely due to the different tectonic settings where the initial measurements have been made. The higher extrapolations ${ }^{77}$ are based on measurements in the Magadi-Natron basin, where remobilized carbon stored under the Tanzanian Craton may contribute to the emissions ${ }^{78}$. Nonetheless, the contribution to the global annual $\mathrm{CO}_{2}$ budget from volcanic and active tectonic sources in the region is significant ${ }^{79}$.

As continental rifts develop, the locus of strain accommodation shifts ${ }^{8}$. Measurements of $\mathrm{CO}_{2}$ emissions and analyses of gases discharged in springs indicate that in the $3 \mathrm{Ma}$ Natron basin (Northern Tanzania) fluid release is concentrated along the border faults where magma bodies ascend; while in the $7 \mathrm{Ma}$ Magadi basin (Southern Kenya) magmatic volatile release is concentrated along intrarift faults in the centre of the basin. This focussing of magma and fluids towards the rift centre occurs as the rift evolves over time and provides a mechanism that may help weaken the crust and result in the transition to strain accommodation that is more focussed ${ }^{77}$.

On a local scale, the spatial patterns of volcanic activity in the EARS are influenced not only by the regional stress field, but also local stresses and structural controls. Only about a third of the historical eruptive fissures or dykes are parallel to the rift axis, and large edifices and eruptive fluxes in particular generate radial stress fields ${ }^{80}$. Fluid flow is strongly controlled by fault systems that enable the transport of lithosphere- and mantle-derived volatiles to reach the surface where they discharge through volcanoes, spring systems or diffusely from the ground. Some volcanoes (e.g. Longonot ${ }^{81}$ and Aluto ${ }^{41,82,83}$; Figs. 1, 4) are dominated by structures formed during the current phase of rifting, including rift-parallel fault systems and volcanic structures such as caldera and crater ring faults. At other 

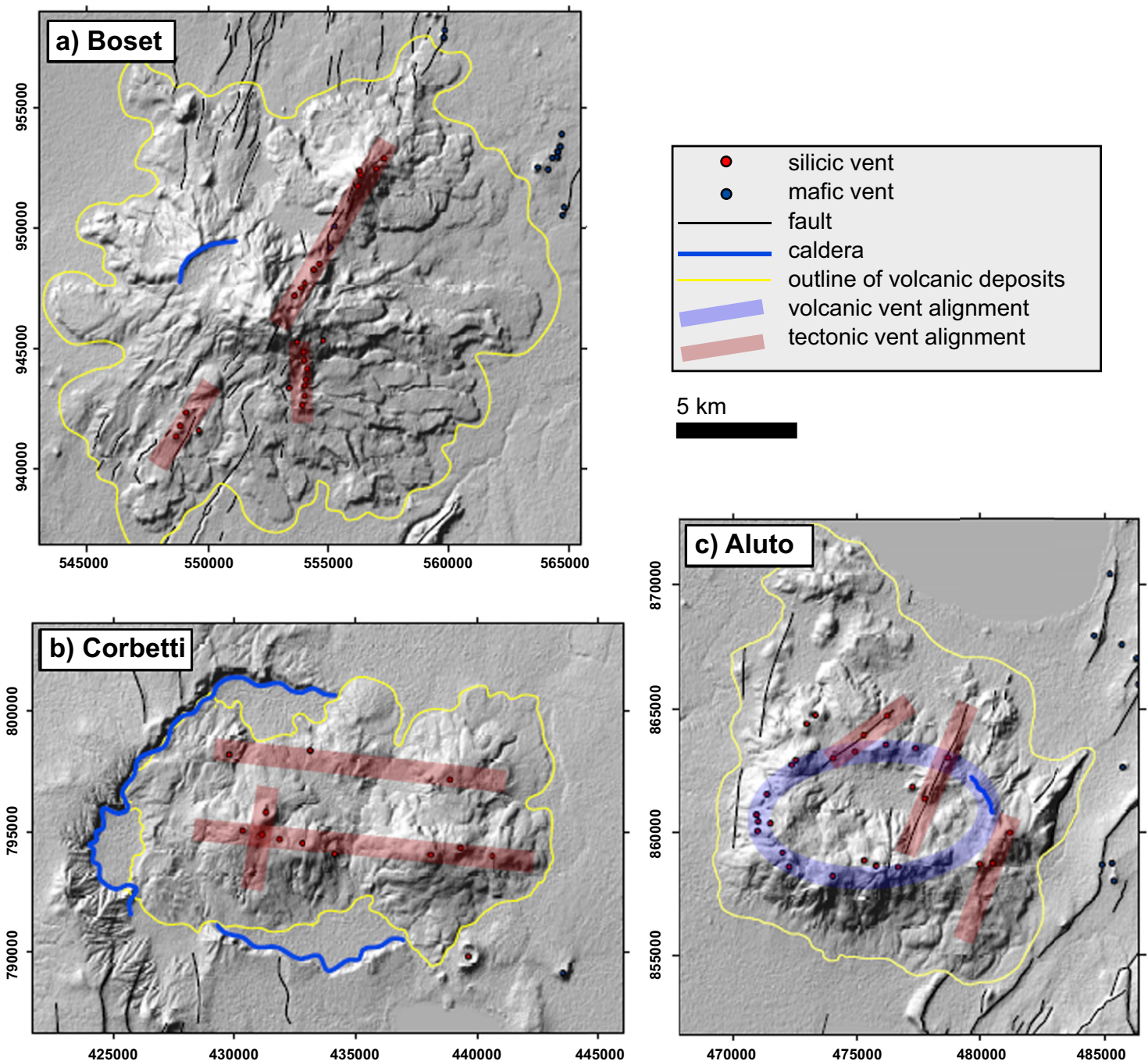

Fig. 4 Contrasting examples of the structural controls on post-caldera volcanism. Structural controls are identified by vents, domes and craters in the Main Ethiopian Rift (adapted from ref. ${ }^{111}$ ). Volcano locations shown on Fig. 1a. a at Boset, trends in vent locations are rift-parallel, aligned with regional faults surrounding the edifice; $\mathbf{b}$ at Corbetti, post-caldera volcanism is aligned with a pre-existing cross rift structure ${ }^{84}$, $\mathbf{c}$ at Aluto, vents and craters follow a proposed caldera rim fault 82 , which has now been buried by subsequent eruptions.

volcanoes (e.g. Corbetti; ref. ${ }^{84}$ Figs. 1, 4), older, inactive faults which may be oblique or perpendicular to the current rift appear to control fluid pathways ${ }^{85}$.

\section{Past eruptions}

Only $\sim 25 \%$ of the Holocene EARS volcanoes have reported historical eruptions ${ }^{80,86}$ and for most EARS volcanoes, the date of the most recent eruption is still not known. Apart from a few exceptions e.g. refs. ${ }^{87,88}$, historical accounts are poorly detailed, with very few accurate observations of pre-eruptive unrest, eruption duration, magnitude and style, or impact on local communities and environment.

Eruption style. Volcanic rocks erupted along the EARS are invariably rich in alkali elements with a reduced oxygen fugacity 89,90 , resulting in a viscosity up to two orders of magnitude lower than their calc-alkaline counterparts for a given temperature ${ }^{89,91}$. This relatively low viscosity combined with high volatile contents ${ }^{18}$ has important implications for the outgassing potential of the magmas and thus eruption dynamics ${ }^{19}$. The effect of low viscosity of the magmas is most pronounced in the extreme mobility of the melilite-nephelinite lava flows of Nyiragongo, which have recorded speeds of up to $100 \mathrm{~km} / \mathrm{h}^{92}$. The potential of fractures opening on the volcano's southern lower flanks, as happened in 1977, 2002 and 2021, especially puts the urban area of Goma at risk $\mathrm{k}^{25,93}$ and could potentially also lead to phreatic explosions from lava entering Lake Kivu or highly explosive phreatomagmatic activity if ascending magma were to interact with shallow groundwater and/or lake water ${ }^{94}$.

In the EARS, few historical eruptions have been documented in detail $^{25,36,95}$, and even fewer have ground-based instrumental observations. The largest historical eruption in East Africa was probably the May 1861 CE eruption of Dubbi in Eritrea (Fig. 1e), and which may have resulted in the more than 100 fatalities in this very sparsely populated region ${ }^{87}$. Using a combination of remote sensing imagery, limited eyewitness accounts, and field observations at selected outcrops ${ }^{87}$, the eruptive volume of (basaltic) trachyandesite lava flows is estimated to be $1-3 \mathrm{~km}^{3}$. Reports of ash fall up to $300 \mathrm{~km}$ West of the volcano, and a depositional thickness of $4.5 \mathrm{~m}$ of trachyandesitic to trachytic pyroclastic deposits at $12 \mathrm{~km}$ from the summit and about $50 \mathrm{~cm}$ of ash fall at $50 \mathrm{~km}$ distance 87 , are consistent with at least a VEI or Magnitude 4 eruption. 
A notable recent event was the 2011 eruption of Nabro, located off-axis on the Eritrean-Ethiopian border. This eruption generated an extremely $\mathrm{SO}_{2}$-rich, but seemingly ash-poor, plume that reached the lower stratosphere (ca. $15-17 \mathrm{~km}$ ) and emitted a total of ca. $4.5 \mathrm{Tg}$ of $\mathrm{SO}_{2}$, one of the largest emissions of volcanic $\mathrm{SO}_{2}$ since the 1991 eruption of Mount Pinatubo ${ }^{96}$. On the ground, the eruption generated two trachybasaltic-trachyandesitic lava flows, one extending to ca. $15 \mathrm{~km}$, and a tephra blanket of unconstrained thickness ${ }^{95,97}$. Other notable historical eruptions have occurred in the Dabbahu Manda Hararo segment, associated with its 2005-2010 rifting episode ${ }^{63}$ and at Erta' Ale, which has regular lava lake overflows and/or effusive eruptions from flank fissures. The most recent of these started in January 2017 and lasted at least 18 months ${ }^{69}$.

Due to the paucity of historical records, information on past eruptions from most volcanoes of the EARS, including many caldera systems, relies solely on the geological record. Widespread, thick pyroclastic units both on land and in lacustrine sequences document past explosive eruptions from the trachyte and phonolite volcanoes of Kenya and Tanzania ${ }^{98-100}$. Detailed mapping of the Rungwe Pumice deposit suggests it was formed by a Plinian eruption of Rungwe volcano with a column ca. $30 \mathrm{~km}$ above sea level and ash dispersal over $>1000 \mathrm{~km}^{2}{ }^{100}$. Sustained explosive Plinian-style eruptions may also occur from peralkaline rhyolite magmas of the MER ${ }^{15,101}$.

Pumice cones have been identified at several EARS calderas ${ }^{15,102-104}$ and were in the past considered to be the rhyolite equivalent of strombolian scoria cones. However, a more detailed evaluation of fall deposits at Aluto ${ }^{15,105}$ and the pyroclasts embedded within them ${ }^{102}$ show that these pumice cones form during highly unsteady sub-Plinian eruptions, where the frequently collapsing plumes generate pyroclastic density currents. The proximal deposits gradually generate a cone-shape landform, which is often breached by a rhyolitic or obsidian lava flow towards the end of the eruption ${ }^{102,103}$. Individual phreatomagmatic vents, including tuff rings and maars, are known near many present-day large surface water bodies and/or important faults ${ }^{16,106}$, including in large fields of monogenetic cones and in the Manyara Rift, North Tanzania, and the Albertine Rift in Uganda $^{107}$. Thus, the complex and multi-hazard nature of eruptions in the EARS needs to be considered when performing quantitative hazard assessments.

Holocene eruption history. Establishing a frequency-magnitude relationship of Holocene eruptions requires constraints on absolute chronology, most commonly provided by radiocarbon dating of charcoal entrained within the deposits or in the underlying palaeosols 101,108 and/or macrofossils or bulk sediment from lacustrine archives ${ }^{15,105,109}$. However, at many EARS volcanoes, little to no suitable material is preserved in the terrestrial sequences, partially because many studied deposits result from pyroclastic fall, which is less likely to trap and char vegetation, and/or because palaeosoils in several places (e.g. across the Ethiopian and Kenyan rifts) are organic-poor. Advancements in analytical precision of ${ }^{36} \mathrm{Ar}-{ }^{39} \mathrm{Ar}$ dating means that Holocene whole-rock or single phenocryst samples can now be dated, although the number of available dates for young deposits remains limited ${ }^{98,110}$.

Lacustrine records often preserve ash deposits of moderateintensity and/or distal eruptions, providing an important additional constraint on eruption recurrence intervals and the distal dispersal patterns of volcanic ash ${ }^{105,109}$. However, the complexity in eruptive style recorded by proximal terrestrial sequences is not detectable in the distal lacustrine records, making reconciliation challenging (Figs. 5, 6). Nonetheless, integrated studies of terrestrial-lacustrine archives have been conducted at several EARS volcanoes (e.g., Rungwe, Aluto, Corbetti). These show more frequent eruptions than were previously expected based on the historical record alone, with average recurrence intervals of the order of $10^{2}-10^{3}$ years ${ }^{15,17,109}$.

At some volcanoes, e.g. the basaltic complexes in Afar, effusive eruptions dominate, and in such cases, mapping of lava flow units using high-resolution satellite imagery, sometimes combined with ${ }^{36} \mathrm{Ar}-{ }^{39} \mathrm{Ar}$ chronology can provide constraints on the longterm eruptive rates of volcanic complexes ${ }^{110-112}$. For example, most of the Gudda-Bericha (also "Boset Volcanic Complex", Fig. 1e) edifice is thought to have built above its MER rift floor in the last $30 \mathrm{ka}$, with activity alternating between the main centres of the complex within this timeframe ${ }^{110}$. The total estimated post-caldera volumes of Aluto and Corbetti relative to the age of their caldera-forming eruptions, yield long-term eruptive rates of order $0.08-0.09 \mathrm{~km}^{3} / \mathrm{ka}$. At other volcanoes in the MER with lower post-caldera volumes, these rates may be much lower, though the age of their caldera-forming events is poorly constrained $^{16}$. At Alu-Dalafilla (Fig. 1a), a complicated pattern of both fissure-dominated basaltic and central silicic eruptions emerges with a total erupted volume of the most recent edifices estimated to be between 0.5 and $2.4 \mathrm{~km}^{3}$, though absolute chronology is not constrained ${ }^{112}$. Despite these advances, reconstructing an integrated view of the effusive-explosive eruptive history at volcanic complexes remains challenging.

\section{Managing volcanic risks in sub-Saharan Africa}

Approaches to hazard assessment. Quantitative volcanic hazard assessment has rarely been applied in East Africa; the 2015 Global Assessment of Risk could only provide well-constrained hazard scores for $6 \%$ of volcanoes in the region ${ }^{1}$. Volcano-geological studies are critical for establishing frequency-magnitude relationships of past and therefore possible future eruptions (Fig. 6), but attempts at reconstructing a comprehensive eruption dataset for the EARS face several limitations including the limited absolute chronology and poor deposit preservation (see Section Holocene eruption history). Expert elicitation, which uses a series of guided questions to document a group of experts' mental models of uncertain quantities, can be used to enhance quantitative estimates of frequency-magnitude relationships based on reconnaissance-style surveys alone ${ }^{113,114}$. This allows the inclusion of events for which no geological constraints exist, such as pre-historic eruptions of small magnitude that are not preserved and has been applied to several volcanoes in East Africa, including Aluto and Corbetti in Ethiopia ${ }^{113,114}$.

Probabilistic volcanic hazard assessment has previously been applied in East Africa to evaluate the conditional probability of inundation by lava flows ${ }^{115}$ or pyroclastic density currents ${ }^{103}$. This approach uses statistical tools to estimate vent opening location, and numerical models to simulate physical processes, where possible informed by field observations. At Aluto, the wide spatial distribution of vent locations, primarily constrained by the caldera ring fault, greatly influences (increases) the area that can potentially be impacted by pyroclastic density currents given a pumice cone eruption. The central caldera floor, home to an estimated 3000 people, a school, and a small geothermal facility, shows a $12 \%$ conditional probability of inundation by pyroclastic density currents given an eruption ${ }^{103}$. However, historical and geological observations show that EARS eruptions are more complex than conveyed in these simple models, and may involve multiple hazards.

A further step is to incorporate both volcanological data and dedicated hazard assessments into an integrated probabilistic event tree model that simulates conditional scenarios ${ }^{116}$. Even at 

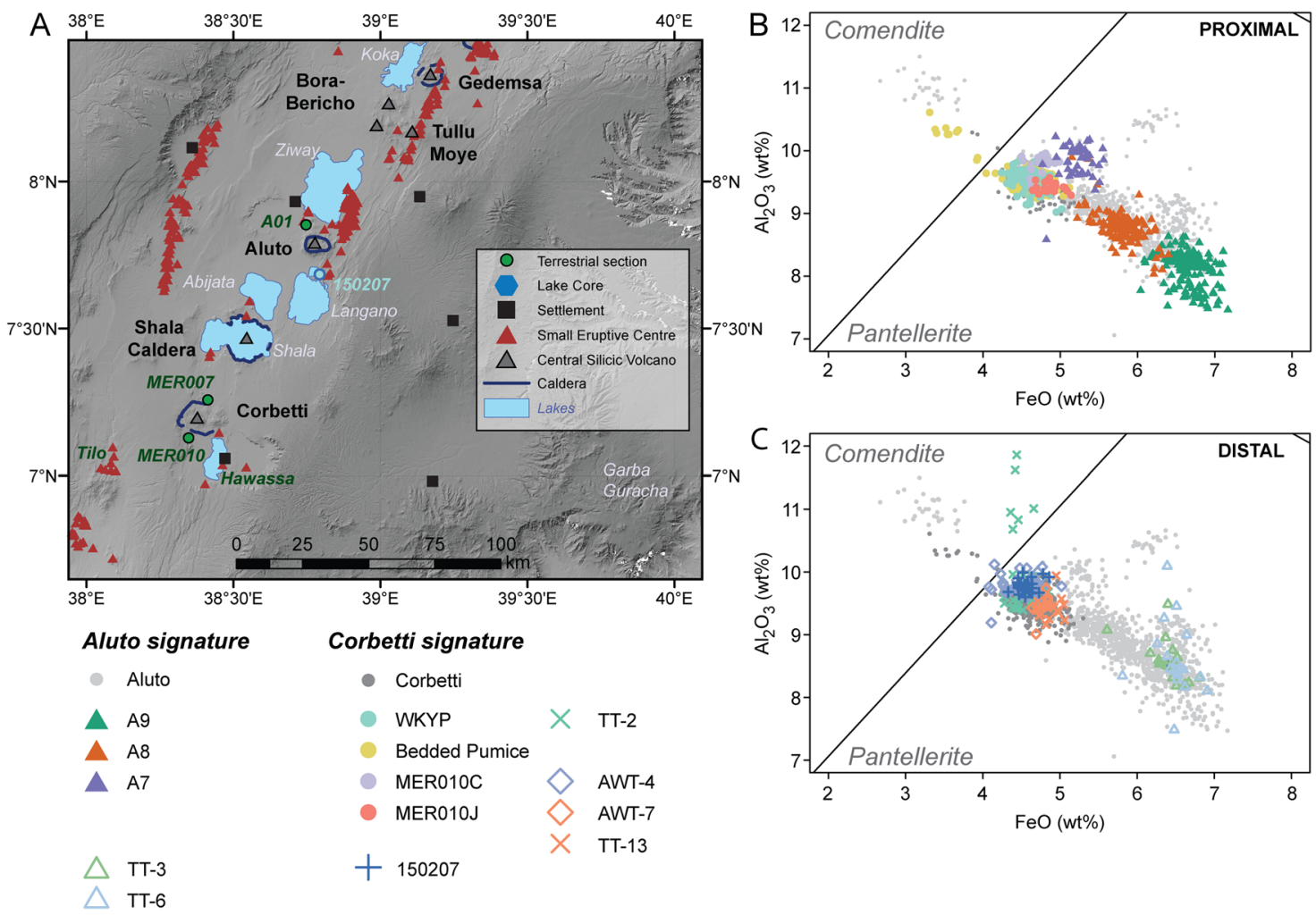

Fig. 5 Geochemistry of Central Main Ethiopian Rift Volcanoes. A Map showing type sections of pyroclastic stratigraphy (green dots) and lake sediment cores (blue pentagons) near Aluto and Corbetti volcanoes in the Main Ethiopian Rift. All show multiple volcanic ash layers that can be attributed to Aluto or Corbetti and demonstrate the potential of developing a regional-scale multi-volcano tephrostratigraphic framework. The light green dot to the south of Aluto shows a locality of a pyroclastic deposit (150207) that has a Corbetti signature. Modified after ${ }^{10}$. B Chemical signatures of Aluto and Corbetti proximal deposits. C Chemical signatures of Aluto and Corbetti distal deposits The Corbetti signature plots as a cluster near $9-10 \mathrm{wt} \% \mathrm{Al}_{2} \mathrm{O}_{3}$ and $4-5 \mathrm{wt} \%$ $\mathrm{FeO}$, whereas the Aluto chemical compositions partially overlap this cluster, but span a much wider range and are thus easier to distinguish.

Aluto, which could currently be considered the best-studied volcano in the EARS, i.e. with the most diverse dataset available, the epistemic uncertainty (largely driven by data availability) remains relatively large, with e.g. an estimated long-term probability of at least one silicic eruption at Aluto in the next 50 years between 2 and $35 \%{ }^{116}$. However, the existing event tree model serves as a framework that can easily be adapted when new data become available (e.g. during an episode of volcano-seismic unrest or eruption).

In addition to understanding and quantifying physical hazards, their potential timescales and impact areas, a quantitative approach to understanding risk and risk perception is also essential. To this end, a precise view of population exposure and the development of population vulnerability indices can highlight strong spatial variations, as is the case in the city of Goma, exposed to volcanic hazards from Nyiragongo ${ }^{117}$. This information can then be combined with estimated impact areas of volcanic hazards (e.g. ref. ${ }^{115}$ ) to better inform risk management and potentially identify priorities towards risk reduction strategies.

Partnerships for developing resilience. Disaster risk reduction and climate change adaptation are key components of the UN Sustainable Development Goals, and governments across Africa are establishing frameworks to protect the lives of people and minimize property damage due to natural disasters. For example, Ethiopia has developed a multi-sector and multi-agency platform for disaster risk management; however, the emphasis is on food security because the long-recurrence intervals and lack of recent disasters caused by eruptions and earthquakes mean that geohazards are considered lower priority. Instead, investment in volcanology is focussed on the opportunities provided by geothermal power and geotourism.

Recent damaging events in the EARS serve as a useful reminder of the hazards associated with continental rifting, but do not reflect the potential impacts of a large magnitude earthquake or eruption in a densely populated region. For example, the 2011 eruption of Nabro occurred on the sparsely populated border between Ethiopia and Eritrea, but even so 12,000 residents selfevacuated, at least 7 fatalities were recorded, two villages were completely destroyed and economic losses were estimated at $\$ 3$ million ${ }^{95}$. Such events attract attention from the international scientific and aid communities, but this is not always accompanied by long-term investment in local capacity or monitoring facilities.

The East and Southern Africa Regional Seismological working group (ESARSWG) has been cooperating to compile a regional earthquake catalogue using data sourced from networks of permanent and temporary seismic stations in Eritrea, Ethiopia, Kenya, Uganda, Tanzania, Malawi, Zambia, Zimbabwe and Mozambique. However, eruption forecasting and alert systems require real-time analysis of small magnitude earthquakes. The Ethiopian national network provides real-time detection of moderate magnitude earthquakes (>M3.5) enabling rapid deployment of the local instrument pool and often attracting an international response ${ }^{60,118}$. While some real-time seismic stations exist elsewhere, most EARS countries rely on notifications from global systems with a higher detection threshold $(>\mathrm{M} 4)$. Consequently, smaller events are often missed, and temporary seismic deployments have retrospectively catalogued 

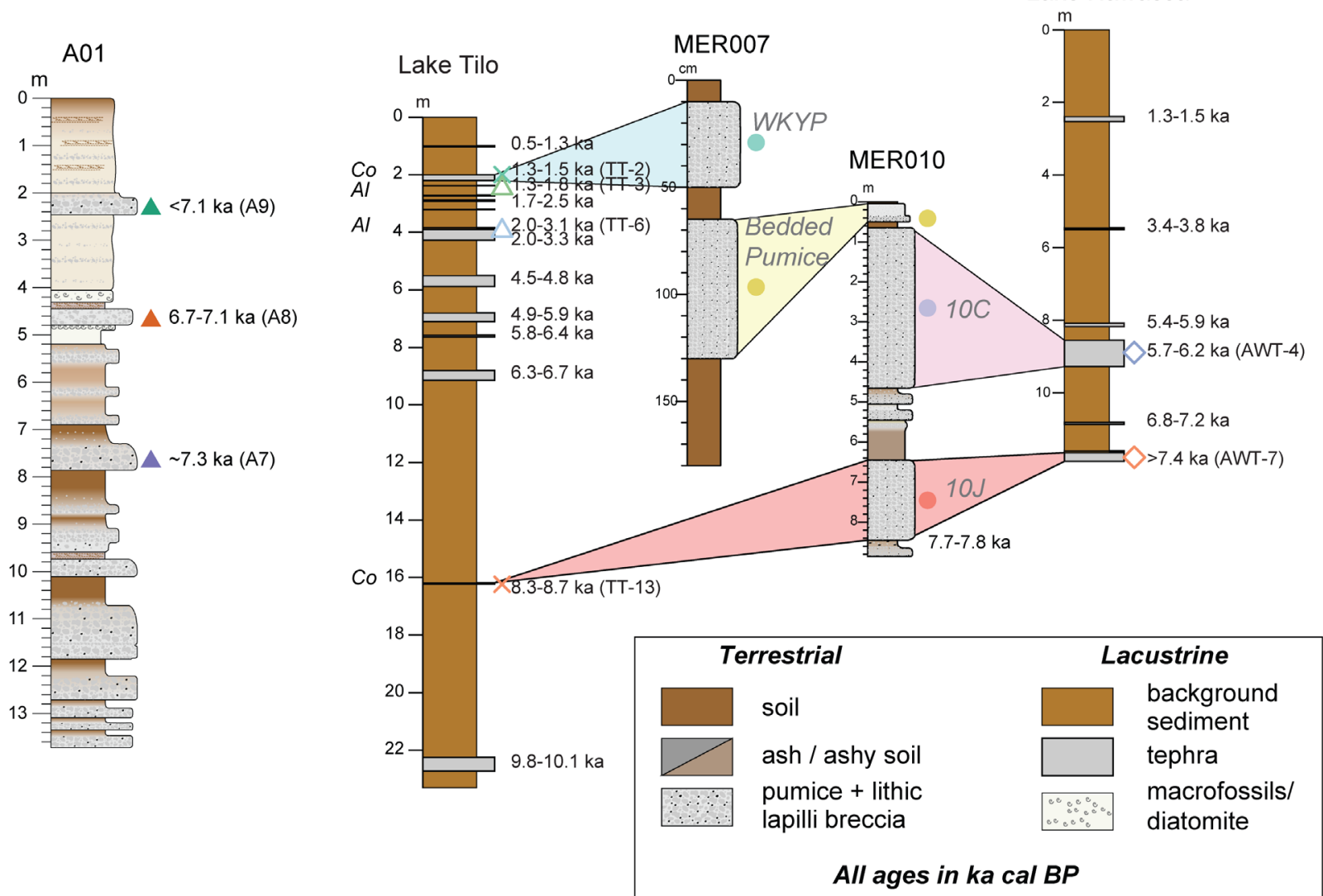

Fig. 6 Eruption chronology of the Central Main Ethiopian Rift. A Schematic stratigraphic column of a terrestrial type section to the NW of Aluto showing a sequence of pyroclastic deposits, soils and lacustrine deposits, demonstrating a history of repeated explosive eruptions throughout the Holocene. B Schematic correlation between terrestrial and lacustrine stratigraphic columns near Corbetti. The Lake Tilo record shows predominantly ash layers of Corbetti signature, with the exception of two (TT-3 and TT-6) that have an Aluto signature. All other schematic logs on the figure have either only Aluto (type section A01) or Corbetti deposits (MER007, MER010 and Lake Hawassa). Co Corbetti, Al Aluto. Modified after ref. ${ }^{10}$, with additional data from ref. ${ }^{108}$. See Fig. 5 for details of locations and chemical compositions.

thousands of small magnitude (0.5-3) events, low-frequency events and swarms characteristic of fluid movement ${ }^{46,48}$. While the development of automated algorithms and satellite systems may mitigate some challenges, unreliable power and telecommunications networks and numerous bureaucratic and logistical challenges mean improved resilience will require political and financial backing. Currently much of this relies on the support of international partners and limited-duration scientific projects $^{119,120}$.

The Sendai Framework for Disaster Risk Reduction emphasizes the importance of understanding disaster risk and enhancing disaster preparedness. The UN Global Assessment of Risk included volcanoes for the first time in $2015^{1}$, and highlighted the challenges faced by many of the world's least developed countries. In the EARS, recent damaging events combined with international research collaborations are driving a growing awareness of geohazards. In Ethiopia, the formation of a working group comprising government institutions, civil protection and infrastructure groups, led the National Disaster Risk Management Commission in 2019 to publicly announce 'a paradigm shift from managing geohazard crises to managing risks'. In Tanzania, the 2007-2008 eruption of Oldoinyo Lengai triggered donorsupported public awareness projects at the universities and public institutions. Sensitization, thereafter, has been done regularly to reduce risk of death and property loss in case of earthquake and volcanic hazards. However, with a few notable exceptions, research in the EARS has been led by international partners aiming to further scientific understanding through reconstructing past events, rather than developing hazard assessments, monitoring networks or scenario planning. While co-designed partnerships with overseas researchers can provide a strong evidence base and strengthen capacity, African institutes bear the responsibility for managing the crises and risks. Thus there is an urgent need to further build human and institutional capacity through multi-disciplinary involvement and funding of academics in African universities, research institutions and geological surveys ${ }^{121}$.

\section{Conclusions and future directions}

The volcanoes of the East African Rift System remain understudied in comparison to many subduction zone volcanoes. Multi-disciplinary studies over the past two decades have unearthed a rich history of volcanic activity and unrest in the EARS, providing new insights into characteristics of the volcanic plumbing systems and the foundation for hazard and risk assessments. Despite this, datasets remain comparatively sparse and many fundamental scientific and societal questions remain unanswered. For example, what drives volcanic eruptions over human and geological timescales, what controls the location of active magmatic systems and their unrest and what are the potential threats from future volcanic activity? The raised 
awareness of volcanic hazards is driving a shift from crisis response to reducing disaster risks, but a lack of institutional and human capacity means managing and mitigating geohazards in sub-Saharan Africa remains challenging. In this section, we briefly summarize some of the remaining scientific challenges associated with volcanism in continental rifts, and the EARS in particular.

Over the past decade, we have been able to image transcrustal magma plumbing systems at various stages of rift development. Vertically, these show the focussing from broad zones of partial melt in the upper mantle to shallow crustal reservoirs which feed basaltic dyke intrusions, or long-lived silicic reservoirs. Transects across the rift show that the deeper parts of this system are often laterally offset from the rift axis (Fig. 2) raising further questions regarding the nature of volcanism along the rift margins and flanks and the connectivity between regions of partial melt both along- and across-rift.

Another major development over the past decade has been the development of eruption chronologies based on geological records from lake sediments, terrestrial sections and lava flow mapping. However, in most cases these remain disconnected, and a full understanding of the magnitude-frequency relationships will require reconciliation of on-shore and offshore records, and of records of explosive and effusive activities. Some eruption styles, such as monogenetic or phreatic eruptions, are poorly recorded in the geological record, and thus challenging to integrate within this framework, despite their prevalence in analogue environments.

Satellite monitoring and short-term instrument deployments have demonstrated that many of the caldera systems in the EARS are currently experiencing unrest, and awareness of volcanic hazards is rising. However, there remain many scientific and societal barriers to developing a forecasting or alert level system capable of responding to changes in behaviour. The available geophysical records provide a snapshot of activity and the vast majority of volcanic systems in the EARS still lack even the most basic monitoring instrumentation. Only long-term, multidisciplinary baseline monitoring integrating ground-based and satellite observations will be capable of distinguishing between background, elevated and escalating states of unrest. In the past few years, enough data have become available to attempt the very first probabilistic hazard assessments and these provide a framework for future studies. However, each volcano has distinct behaviour controlled by the complex interplay between stress, rheology and fluid flow and driven by a range of poorly understood tectonic, magmatic and climate processes. Characterizing each system represents an enormous data gathering challenge followed by interpretations that eventually lead to physicalchemical volcano models, which can only be met by developing infrastructure, expertise and education within African Institutions.

Received: 24 May 2021; Accepted: 3 November 2021;

Published online: 25 November 2021

\section{References}

1. Loughlin, S., Sparks, S., Brown, S., Jenkins, S. \& Vye-Brown, C. Global Volcanic Hazards and Risk (Cambridge University Press, 2015).

2. Rooney, T. O., Bastow, I. D. \& Keir, D. Insights into extensional processes during Magma assisted rifting: evidence from aligned Scoria Cones. J. Volcanol. Geotherm. Res. 201, 83-96 (2011).

3. Ferguson, D. J. et al. Melting during late-stage rifting in Afar is hot and deep. Nature 499, 70-73 (2013).

4. Biggs, J., Anthony, E. Y. \& Ebinger, C. J. Multiple inflation and deflation events at Kenyan volcanoes, East African Rift. Geology 37, 979-982 (2009).
5. Biggs, J., Bastow, I. D., Keir, D. \& Lewi, E. Pulses of deformation reveal frequently recurring shallow magmatic activity beneath the Main Ethiopian Rift. Geochem. Geophys. Geosyst. https://doi.org/10.1029/2011GC003662 (2011).

6. Albino, F. \& Biggs, J. Magmatic processes in the East African Rift system: insights from a 2015-2020 Sentinel-1 InSAR survey. Geochem. Geophys. Geosyst. 22, https://agupubs.onlinelibrary.wiley.com/doi/full/10.1029/ 2020GC009488 (2021).

7. Boyce, A. et al. AFRP20: New P-wavespeed model for the African mantle reveals two whole-mantle plumes below East Africa and neoproterozoic modification of the Tanzania Craton. Geochem. Geophys. Geosyst. 22, e2020GC009302 (2021).

8. Corti, G. Continental rift evolution: from rift initiation to incipient break-up in the Main Ethiopian Rift, East. Afr. Earth Sci. Rev. 96, 1-53 (2009).

9. Ebinger, C. Continental break-up: the East African perspective. Astron Geophys. 46, 2-16 (2005).

10. Carn, S., Fioletov, V., McLinden, C., Li, C. \& Krotkov, N. A decade of global volcanic SO 2 emissions measured from space. Sci. Rep. 7, 44095 (2017).

11. Fischer, T. P. et al. The emissions of CO 2 and other volatiles from the world's subaerial volcanoes. Sci. Rep. 9, 1-11 (2019).

12. Klaudius, J. \& Keller, J. Peralkaline silicate lavas at Oldoinyo Lengai, Tanzania. Lithos 91, 173-190 (2006).

13. Ebinger, C. et al. Crustal structure of active deformation zones in Africa: implications for global crustal processes. Tectonics 36, 3298-3332 (2017).

14. Gallacher, R. J. et al. The initiation of segmented buoyancy-driven melting during continental breakup. Nat. Commun. 7, 1-9 (2016).

15. Fontijn, K. et al. Contrasting styles of post-caldera volcanism along the Main Ethiopian Rift: Implications for contemporary volcanic hazards. J. Volcanol. Geotherm. Res. 356, 90-113 (2018).

16. Hunt, J. A., Mather, T. A. \& Pyle, D. M. Morphological comparison of distributed volcanic fields in the Main Ethiopian Rift using high-resolution digital elevation models. J. Volcanol. Geotherm. Res. 393, 106732 (2020).

17. Gleeson, M. L. et al. Constraining magma storage conditions at a restless volcano in the Main Ethiopian Rift using phase equilibria models. J. Volcanol. Geotherm. Res. 337, 44-61 (2017).

18. Iddon, F. \& Edmonds, M. Volatile-rich magmas distributed through the upper crust in the Main Ethiopian Rift. Geochem. Geophys. Geosyst. 21, e2019GC008904 (2020).

19. Scaillet, B. \& Macdonald, R. Phase relations of peralkaline silicic magmas and petrogenetic implications. J. Petrol. 42, 825-845 (2001).

20. Hutchison, W. et al. The evolution of magma during continental rifting: new constraints from the isotopic and trace element signatures of silicic magmas from Ethiopian volcanoes. Earth Planet. Sci. Lett. 489, 203-218 (2018).

21. Iddon, F. et al. Mixing and crystal scavenging in the Main Ethiopian Rift revealed by trace element systematics in feldspars and glasses. Geochem. Geophys. Geosyst. 20, 230-259 (2019).

22. Macdonald, R. et al. The roles of fractional crystallization, magma mixing, crystal mush remobilization and volatile-melt interactions in the genesis of a young basalt-peralkaline rhyolite suite, the Greater Olkaria Volcanic Complex, Kenya Rift Valley. J. Petrol. 49, 1515-1547 (2008).

23. Bastow, I. D. \& Keir, D. The protracted development of the continent-ocean transition in Afar. Nat. Geosci. 4, 248-250 (2011).

24. Platz, T., Foley, S. F. \& Andre, L. Low-pressure fractionation of the Nyiragongo volcanic rocks, Virunga Province, DR Congo. J. Volcanol. Geotherm. Res. 136, 269-295 (2004).

25. Komorowski, J. \& Karume, K. Nyiragongo (Democratic Republic of Congo), January 2002: a major eruption in the midst of a complex humanitarian emergency. Glob. Vol. Hazard. Risk 273, 273-280 (2015).

26. Wauthier, C., Cayol, V., Kervyn, F. \& d'Oreye, N. Magma sources involved in the 2002 Nyiragongo eruption, as inferred from an InSAR analysis. J. Geophys. Res. Solid Earth 117, B05411 (2012).

27. Global Volcanism Program. Report on Nyiragongo (DR Congo). Bull. Glob. Volcanism Netw. 46, 6 (2021).

28. Albino, F., Smets, B., d'Oreye, N. \& Kervyn, F. High-resolution TanDEM-X DEM: an accurate method to estimate lava flow volumes at Nyamulagira Volcano (DR Congo). J. Geophys. Res. Solid Earth 120, 4189-4207 (2015).

29. Ji, K. H. et al. Deep magma accumulation at Nyamulagira volcano in 2011 detected by GNSS observations. J. Afr. Earth Sci. 134, 824-830 (2017).

30. Demant, A., Lestrade, P., Lubala, R. T., Kampunzu, A. B. \& Durieux, J. Volcanological and petrological evolution of Nyiragongo volcano, Virunga volcanic field, Zaire. Bull. Volcanol. 56, 47-61 (1994).

31. Bosshard-Stadlin, S. A., Mattsson, H. B. \& Keller, J. Magma mixing and forced exsolution of CO2 during the explosive 2007-2008 eruption of Oldoinyo Lengai (Tanzania). J. Volcanol. Geotherm. Res. 285, 229-246 (2014).

32. Fischer, T. P. et al. Upper-mantle volatile chemistry at Oldoinyo Lengai volcano and the origin of carbonatites. Nature 459, 77-80 (2009).

33. de Moor, J. M. et al. Volatile-rich silicate melts from Oldoinyo Lengai volcano (Tanzania): implications for carbonatite genesis and eruptive behavior. Earth Planet. Sci. Lett. 361, 379-390 (2013). 
34. Biggs, J., Chivers, M. \& Hutchinson, M. C. Surface deformation and stress interactions during the 2007-2010 sequence of earthquake, dyke intrusion and eruption in northern Tanzania. Geophys. J. Int. 195, 16-26 (2013).

35. Baer, G., Hamiel, Y., Shamir, G. \& Nof, R. Evolution of a magma-driven earthquake swarm and triggering of the nearby Oldoinyo Lengai eruption, as resolved by InSAR, ground observations and elastic modeling, East African Rift, 2007. Earth Planet. Sci. Lett. 272, 339-352 (2008).

36. De Schutter, A. et al. Ash fall impact on vegetation: a remote sensing approach of the Oldoinyo Lengai 2007-08 eruption. J. Appl. Volcanol. 4, 1-18 (2015)

37. Reiss, M. et al. The impact of complex volcanic plumbing on the nature of seismicity in the developing magmatic natron rift. Tanzan. Front. Earth Sci. 8, 609805 (2021).

38. Gíslason, G., Eysteinsson, H., Björnsson, G. \& Harðardóttir, V. Results of surface Exploration in the Corbetti Geothermal Area, Ethiopia. In World Geothermal Congress, Melbourne, Australia (pp. 19-25).

39. Samrock, F., Grayver, A. V., Bachmann, O., Karakas, Ö. \& Saar, M. O. Integrated magnetotelluric and petrological analysis of felsic magma reservoirs: Insights from Ethiopian rift volcanoes. Earth Planet. Sci. Lett. 559, 116765 (2021).

40. Wilks, M. et al. The coupled magmatic and hydrothermal systems of the restless Aluto caldera, Ethiopia. Front. Earth Sci. 8, 421 (2020).

41. Nowacki, A., Wilks, M., Kendall, J.-M., Biggs, J. \& Ayele, A. Characterising hydrothermal fluid pathways beneath Aluto volcano, Main Ethiopian Rift, using shear wave splitting. J. Volcanol. Geotherm. Res. 356, 331-341 (2018)

42. Whaler, K. \& Hautot, S. The electrical resistivity structure of the crust beneath the northern Main Ethiopian Rift. Geol. Soc. Lond. Spec. Publ. 259, 293-305 (2006).

43. Hammond, J. O. et al. Mantle upwelling and initiation of rift segmentation beneath the Afar Depression. Geology 41, 635-638 (2013).

44. Stuart, G., Bastow, I. \& Ebinger, C. Crustal structure of the northern Main Ethiopian Rift from receiver function studies. Geol. Soc. Lond. Spec. Publ. 259, 253-267 (2006).

45. Kendall, J.-M., Stuart, G., Ebinger, C., Bastow, I. \& Keir, D. Magma-assisted rifting in Ethiopia. Nature 433, 146-148 (2005).

46. Wilks, M. et al. Seismicity associated with magmatism, faulting and hydrothermal circulation at Aluto Volcano, Main Ethiopian Rift. J. Volcanol. Geotherm. Res. 340, 52-67 (2017).

47. Lavayssière, A., Greenfield, T., Keir, D., Ayele, A. \& Kendall, J.-M. Local seismicity near the actively deforming Corbetti volcano in the Main Ethiopian Rift. J. Volcanol. Geotherm. Res. 381, 227-237 (2019).

48. Greenfield, T., Keir, D., Kendall, J. M. \& Ayele, A. Seismicity of the Bora-Tullu Moye Volcanic Field, 2016-2017. Geochem. Geophys.s, Geosyst. 20, 548-570 (2019).

49. Greenfield, T., Keir, D., Kendall, J.-M. \& Ayele, A. Low-frequency earthquakes beneath Tullu Moye volcano, Ethiopia, reveal fluid pulses from shallow magma chamber. Earth Planet. Sci. Lett. 526, 115782 (2019).

50. Patlan, E., Wamalwa, A., Kaip, G. \& Velasco, A. A. Ambient noise crosscorrelation study of Menengai Caldera: geothermal prospect in the Central Kenya Dome. Geotherm. Resour. Counc. Trans. 37, 1037-1042 (2013).

51. Gottsmann, J., Biggs, J., Lloyd, R., Biranhu, Y. \& Lewi, E. Ductility and compressibility accommodate high magma flux beneath a silicic continental rift caldera: Insights from Corbetti caldera (Ethiopia). Geochem. Geophys. Geosyst. 21, e2020GC008952 (2020).

52. Lloyd, R. et al. Sustained uplift at a continental rift Caldera. J. Geophys. Res. Solid Earth 123, 5209-5226 (2018).

53. Hutchison, W. et al. Causes of unrest at silicic calderas in the East African Rift: new constraints from InSAR and soil-gas chemistry at Aluto volcano, Ethiopia. Geochem. Geophys. Geosyst. 17, 3008-3030 (2016).

54. Biggs, J., Robertson, E. \& Cashman, K. The lateral extent of volcanic interactions during unrest and eruption. Nat. Geosci. 9, 308 (2016)

55. Kombe, E. Y. \& Muguthu, J. Geothermal energy development in East Africa: barriers and strategies. J. Energy Res. Rev. 2, 1-6 (2019).

56. Rowland, J. V., Wilson, C. J. N. \& Gravley, D. M. Spatial and temporal variations in magma-assisted rifting, Taupo Volcanic Zone, New Zealand. J. Volcanol. Geotherm. Res. 190, 89-108 (2010).

57. Wright, T. J. et al. Geophysical constraints on the dynamics of spreading centres from rifting episodes on land. Nat. Geosci. 5, 242-250 (2012).

58. Field, L., Blundy, J., Calvert, A. \& Yirgu, G. Magmatic history of Dabbahu, a composite volcano in the Afar Rift, Ethiopia. Geol. Soc. Am. Bull. 125, 128-147 (2013).

59. Wright, T. J. et al. Magma-maintained rift segmentation at continental rupture in the 2005 Afar dyking episode. Nature 442, 291-294 (2006).

60. Ayele, A. et al. September 2005 mega-dike emplacement in the MandaHarraro nascent oceanic rift (Afar depression). Geophys. Res. Lett. 36, L20306 (2009).

61. Hamling, I., Wright, T., Calais, E., Bennati, L. \& Lewi, E. Stress transfer between thirteen successive dyke intrusions in Ethiopia. Nat. Geosci. 3, 713-717 (2010).
62. Belachew, M. et al. Comparison of dike intrusions in an incipient seafloorspreading segment in Afar, Ethiopia: Seismicity perspectives. J. Geophys. Res. Solid Earth 116, B06405 (2011).

63. Ferguson, D. J. et al. Recent rift-related volcanism in Afar, Ethiopia. Earth Planet. Sci. Lett. 292, 409-418 (2010).

64. Hammond, J. O. S. et al. The nature of the crust beneath the Afar triple junction: evidence from receiver functions. Geochem. Geophys. Geosyst. 12, Q12004 (2011).

65. Grandin, R. et al. Sequence of rifting in Afar, Manda-Hararo rift, Ethiopia, 2005-2009: Time-space evolution and interactions between dikes from interferometric synthetic aperture radar and static stress change modeling. $J$ Geophys. Res. 115, B10413 (2010).

66. Desissa, M. et al. A mantle magma reservoir beneath an incipient mid-ocean ridge in Afar, Ethiopia. Nat. Geosci. 6, 861-865 (2013).

67. Johnson, N. et al. Magma imaged magnetotellurically beneath an active and an inactive magmatic segment in Afar, Ethiopia. Geol. Soc. Lond. Spec. Publ. 420, 105-125 (2016).

68. Pagli, C. et al. Dynamics of an axial magma chamber at the Erta Ale slow spreading segment. Nat. Geosci. 5, 284-288 (2012).

69. Moore, C., Wright, T., Hooper, A. \& Biggs, J. The 2017 Eruption of Erta 'Ale Volcano, Ethiopia: insights Into the Shallow Axial Plumbing System of an Incipient Mid-Ocean Ridge. Geochem. Geophys., Geosyst. 20, 5727-5743 (2019).

70. Nobile, A. et al. Dike-fault interaction during the 2004 Dallol intrusion at the northern edge of the Erta Ale Ridge (Afar, Ethiopia). Geophys. Res. Lett. https://doi.org/10.1029/2012GL053152 (2012).

71. Amelung, F., Oppenheimer, C., Segall, P. \& Zebker, H. Ground deformation near Gada 'Ale Volcano, Afar, observed by radar interferometry. Geophys. Res. Lett. 27, 3093-3096 (2000).

72. Field, L. et al. Integrated field, satellite and petrological observations of the November 2010 eruption of Erta Ale. Bull. Volcanol. 74, 2251-2271 (2012).

73. Barry, P. H. et al. Helium and carbon isotope systematics of cold "mazuku" CO\$_\$ vents and hydrothermal gases and fluids from Rungwe Volcanic Province, southern Tanzania. Chem. Geol. 339, 141-156 (2013).

74. De Moor, J. et al. Gas chemistry and nitrogen isotope compositions of cold mantle gases from Rungwe Volcanic Province, southern Tanzania. Chem. Geol. 339, 30-42 (2013).

75. Lee, H. et al. Incipient rifting accompanied by the release of subcontinental lithospheric mantle volatiles in the Magadi and Natron basin, East Africa. J. Volcanol. Geotherm. Res. 346, 118-133 (2017).

76. Hunt, J. A., Zafu, A., Mather, T. A., Pyle, D. M. \& Barry, P. H. Spatially variable CO 2 degassing in the main Ethiopian Rift: implications for Magma storage, volatile transport, and Rift-related emissions. Geochem. Geophys. Geosyst. 18, 3714-3737 (2017).

77. Lee, H. et al. Massive and prolonged deep carbon emissions associated with continental rifting. Nat. Geosci. 9, 145-149 (2016).

78. Muirhead, J. D. et al. Displaced cratonic mantle concentrates deep carbon during continental rifting. Nature 582, 67-72 (2020).

79. Werner, C. et al. Deep Carbon Past to Present (Cambridge University Press, 2019).

80. Wadge, G., Biggs, J., Lloyd, R. \& Kendall, J.-M. Historical volcanism and the state of stress in the East African Rift System. Front. Earth Sci. 4, 86 (2016).

81. Robertson, E. et al. Diffuse degassing at Longonot volcano, Kenya: Implications for CO 2 flux in continental rifts. J. Volcanol. Geotherm. Res. 327, 208-222 (2016).

82. Hutchison, W., Mather, T. A., Pyle, D. M., Biggs, J. \& Yirgu, G. Structural controls on fluid pathways in an active rift system: a case study of the Aluto volcanic complex. Geosphere 11, 542-562 (2015).

83. Braddock, M. et al. Satellite observations of fumarole activity at Aluto volcano, Ethiopia: implications for geothermal monitoring and volcanic hazard. $J$ Volcanol. Geotherm. Res. 341, 70-83 (2017).

84. Lloyd, R. et al. Evidence for cross rift structural controls on deformation and seismicity at a continental rift caldera. Earth Planet. Sci. Lett. 487, 190-200 (2018).

85. Robertson, E., Biggs, J., Cashman, K., Floyd, M. \& Vye-Brown, C. Influence of regional tectonics and pre-existing structures on the formation of elliptical calderas in the Kenyan Rift. Geol. Soc. Lond. Spec. Publ. 420, SP420. 412 (2015).

86. Venzke, E (ed.). Global Volcanism Program, 2013. Volcanoes of the World, v. 4.10.3. https://volcano.si.edu/gvp_cite.cfm (Smithsonian Institution, 2021).

87. Wiart, P. \& Oppenheimer, C. Largest known historical eruption in Africa: Dubbi volcano, Eritrea, 1861. Geology 28, 291-294 (2000).

88. Yirgu, G., Ferguson, D. J., Barnie, T. D. \& Oppenheimer, C. in Extreme Natural Hazards, Disaster Risks and Societal Implications, 200-213 (Cambridge University Press, 2014).

89. Di Genova, D. et al. The rheology of peralkaline rhyolites from Pantelleria Island. J. Volcanol. Geotherm. Res. 249, 201-216 (2013). 
90. Stabile, P. et al. Viscosity of pantelleritic and alkali-silicate melts: Effect of $\mathrm{Fe}$ redox state and $\mathrm{Na} /(\mathrm{Na}+\mathrm{K})$ ratio. Chem. Geol. 442, 73-82 (2016).

91. Giordano, D., Romano, C., Papale, P. \& Dingwell, D. The viscosity of trachytes, and comparison with basalts, phonolites, and rhyolites. Chem. Geol. 213, 49-61 (2004).

92. Tazieff, H. An exceptional eruption: Mt. Niragongo, Jan. 10 th, 1977. Bull. Volcanol. 40, 189-200 (1977).

93. Tedesco, D. et al. January 2002 volcano-tectonic eruption of Nyiragongo volcano, Democratic Republic of Congo. J. Geophys. Res. Solid Earth 112 B09202 (2007)

94. Poppe, S. et al. Holocene phreatomagmatic eruptions alongside the densely populated northern shoreline of Lake Kivu, East African Rift: timing and hazard implications. Bull. Volcanol. 78, 1-17 (2016).

95. Goitom, B. et al. First recorded eruption of Nabro volcano, Eritrea, 2011. Bull. Volcanol. 77, 85 (2015).

96. Theys, N. et al. Volcanic SO 2 fluxes derived from satellite data: a survey using OMI, GOME-2, IASI and MODIS. Atmos. Chem. Phys. 13, 5945-5968 (2013).

97. Donovan, A., Blundy, J., Oppenheimer, C. \& Buisman, I. The 2011 eruption of Nabro volcano, Eritrea: perspectives on magmatic processes from melt inclusions. Contributions Mineral. Petrol. 173, 1-23 (2018).

98. Blegen, N. et al. The Menengai Tuff: a 36 ka widespread tephra and its chronological relevance to Late Pleistocene human evolution in East Africa. Quat. Sci. Rev. 152, 152-168 (2016).

99. Mibei, G. et al. Eruptive history and volcano-tectonic evolution of Paka volcanic complex in the northern Kenya rift: Insights into the geothermal heat source. J. Afr. Earth Sci. 173, 103951 (2021).

100. Fontijn, K. et al. The 4-ka Rungwe Pumice (South-Western Tanzania): a windstill Plinian eruption. Bull. Volcanol. 73, 1353-1368 (2011).

101. Rapprich, V. et al. Wendo Koshe Pumice: The latest Holocene silicic explosive eruption product of the Corbetti Volcanic System (Southern Ethiopia). J. Volcanol. Geotherm. Res. 310, 159-171 (2016).

102. Clarke, B. et al. Fluidal pyroclasts reveal the intensity of peralkaline rhyolite pumice cone eruptions. Nat. Commun. 10, 1-10 (2019).

103. Clarke, B., Tierz, P., Calder, E. \& Yirgu, G. Probabilistic volcanic hazard assessment for pyroclastic density currents from pumice cone eruptions at Aluto volcano, Ethiopia. Front. Earth Sci. 8, 348 (2020).

104. Clarke, M. C. G., Woodhall, D. G., Allen, D. \& Darling, G. Geology, volcanological and hydrological controls on the occurrence of geothermal activity in the area surrounding Lake Naivasha, Kenya.(British Geological Survey and Kenyan Ministry of Energy, 1990).

105. McNamara, K. et al. Using lake sediment cores to improve records of volcanism at Aluto volcano in the main Ethiopian rift. Geochem. Geophys. Geosyst. 3164-3188 (2018).

106. Fontijn, K. et al. Tectonic control over active volcanism at a range of scales: case of the Rungwe Volcanic Province, SW Tanzania; and hazard implications. J. Afr. Earth Sci. 58, 764-777 (2010).

107. Delcamp, A. et al. Control of the stress field and rift structures on the distribution and morphology of explosive volcanic craters in the Manyara and Albertine rifts. J. Afr. Earth Sci. 150, 566-583 (2019).

108. Fontijn, K. et al. Holocene explosive eruptions in the Rungwe volcanic province, Tanzania. J. Volcanol. Geotherm. Res. 196, 91-110 (2010).

109. Martin-Jones, C. M. et al. Recurrent explosive eruptions from a high-risk Main Ethiopian Rift volcano throughout the Holocene. Geology 45, 1127-1130 (2017).

110. Siegburg, M. et al. Geological evolution of the Boset-Bericha volcanic complex, Main Ethiopian Rift: 40Ar/39Ar evidence for episodic Pleistocene to Holocene volcanism. J. Volcanol. Geotherm. Res. 351, 115-133 (2018).

111. Hunt, J. A., Pyle, D. M. \& Mather, T. A. The geomorphology, structure, and lava flow dynamics of peralkaline rift volcanoes from high-resolution digital elevation models. Geochem. Geophys. Geosyst. 20, 1508-1538 (2019).

112. Watts, E. J. et al. Evolution of the Alu-Dalafilla and Borale volcanoes, Afar, Ethiopia. J. Volcanol. Geotherm. Res. 408, 107094 (2020).

113. Jenkins, S., Mee, K., Engwell, S., Lark, M. \& Loughlin, S. C. in Development of Natural Disaster Risk Profiles for Sub-Saharan Africa, vol. 43 (World Bank/ Global Facility for Disaster Risk Reduction and Recovery, 2015).

114. Crummy, J. et al. Elicitation of potential future explosive silicic eruption scenarios at Corbetti and Aluto volcanoes, Ethiopia. Br. Geol. Surv. Open FIle Rep. 66, 27 (2018).

115. Favalli, M., Chirico, G. D., Papale, P., Pareschi, M. T. \& Boschi, E. Lava flow hazard at Nyiragongo volcano, DRC. Bull. Volcanol. 71, 363-374 (2009).
116. Tierz, P. et al. Event trees and epistemic uncertainty in long-term volcanic hazard assessment of rift volcanoes: the example of Aluto (Central Ethiopia) Geochem. Geophys. Geosyst. 21, e2020GC009219 (2020).

117. Michellier, C. et al. Evaluating population vulnerability to volcanic risk in a data scarcity context: the case of Goma city, Virunga volcanic province (DRCongo). Int. J. Disaster Risk Reduct. 45, 101460 (2020).

118. Temtime, T., Biggs, J., Lewi, E. \& Ayele, A. Evidence for Active Rhyolitic dike intrusion in the Northern Main Ethiopian Rift from the 2015 Fentale Seismic Swarm. Geochem. Geophys. Geosyst. 21, e2019GC008550 (2020).

119. Lazecký, M. et al. LiCSAR: An automatic InSAR tool for measuring and monitoring tectonic and volcanic activity. Remote Sens. 12, 2430 (2020).

120. Jones, J. R., Stamps, D. S., Daniels, M. D. \& Hook, N. in AGU Fall Meeting Abstracts (American Geophysical Union, 2018).

121. Mulugeta, G. 2009. in Geophysical Hazards 71-81. (Springer, 2009).

122. Robertson, E. et al. Diffuse degassing at Longonot volcano, Kenya: Implications for $\mathrm{CO} 2$ flux in continental rifts. J. Volcanol. Geotherm. Res. 327, 208-222 (2016).

123. Robertson, E. Magma storage and transport at Kenyan Rift volcanoes: a remote sensing perspective. $\mathrm{PhD}$ thesis, University of Bristol, UK, (2015).

\section{Acknowledgements}

J.B., K.F., K.W., T.W. and A.A. were supported by NERC Large Grant RiftVolc (NE/ L013649/1, NE/L013932/1, NE/L013533/1, NE/L013649/1); A.A. acknowledges financial support of ISP (International Science Program) of Uppsala University. T.W., K.W. and A.A. were supported by NERC Afar Rift Consortium (NE/E007414/1, NE/E007147/1); K.F. acknowledges support from F.R.S.-FNRS MIS grant F.4515.20. W.H. acknowledges support from a UKRI Future Leaders Fellowship (MR/S033505/1). T.F. acknowledges US National Science Foundation GeoPRISMS grant 1654433. Geophysical field campaigns in Ethiopia were supported by equipment from the Natural Environment Research Council Geophysical Equipment Facility, the Geophysical Instrument Pool Potsdam (part of GeoForschungsZentrum) and Dublin Institute for Advanced Studies. COMET is the NERC Centre for the Observation and Modelling of Earthquakes, Volcanoes and Tectonics, a partnership between UK Universities and the British Geological Survey. We thank Juliane Hübert for replotting Fig. 2a, c.

\section{Author contributions}

J.B. conceived the article and prepared the outline. J.B., K.F., T.W., K.W. and T.F. wrote the main manuscript and A.A. and E.K. provided verbal input. K.F. and W.H. prepared the figures. All authors reviewed the manuscript.

\section{Competing interests}

The authors declare no competing interests.

\section{Additional information}

Correspondence and requests for materials should be addressed to Juliet Biggs.

Reprints and permission information is available at http://www.nature.com/reprints

Publisher's note Springer Nature remains neutral with regard to jurisdictional claims in published maps and institutional affiliations.

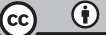

Open Access This article is licensed under a Creative Commons Attribution 4.0 International License, which permits use, sharing, adaptation, distribution and reproduction in any medium or format, as long as you give appropriate credit to the original author(s) and the source, provide a link to the Creative Commons license, and indicate if changes were made. The images or other third party material in this article are included in the article's Creative Commons license, unless indicated otherwise in a credit line to the material. If material is not included in the article's Creative Commons license and your intended use is not permitted by statutory regulation or exceeds the permitted use, you will need to obtain permission directly from the copyright holder. To view a copy of this license, visit http://creativecommons.org/ licenses/by/4.0/.

(C) The Author(s) 2021 